\title{
Biogenetic Linkage among Ecotopes within Matera-Sassi (Italy) Habitat
}

\author{
Giovanni Figliuolo, Mario Nuzzi \\ Dipartimento di Culture Europee e del Mediterraneo (DiCEM), Università degli Studi della Basilicata, Matera, Italy \\ Email: giovanni.figliuolo@unibas.it
}

How to cite this paper: Figliuolo, G. and Nuzzi, M. (2021) Biogenetic Linkage among Ecotopes within Matera-Sassi (Italy) Habitat. Open Journal of Genetics, 11, 63-76. https://doi.org/10.4236/ojgen.2021.114007

Received: August 24, 2021

Accepted: October 31, 2021

Published: November 3, 2021

Copyright $\odot 2021$ by author(s) and Scientific Research Publishing Inc. This work is licensed under the Creative Commons Attribution International License (CC BY 4.0).

http://creativecommons.org/licenses/by/4.0/

\begin{abstract}
In the management of UNESCO cultural sites of significant environmental importance, the erroneous assumption that the environment is independent of biological heritage often prevails. The mapping of phylogenetic resources in the ancient city Matera-Sassi (MS) and the multivariable analysis at the level of ecotope and habitat have made it possible to identify the consistency of the plant genetic heritage and the biogenetic associations between the different ecotopes through the species they host. The bioclimatic variables and geomorphology of MS define an ecological niche refuge for rare or absent species in the surrounding landscape (e.g., Campanula versicolor L., Centranthus ruber (L.) Dc., Capparis spinosa L., Cymbalaria muralis Hill, Crepis spp., Lavathera arborea L.) The total floristic capital in MS amounts to 190 species belonging to 59 different botanical families; $80 \%$ are native species and only $4 \%$ are invasive. About half are Mediterranean with a moderate presence (17\%) of cosmopolitan and sub-cosmopolitan; $5 \%$ are endemic species. Autogenic ecotopes (Type I) represented by "Pleistocene limestone" and "House wall" contribute to the variation of total biodiversity through Endemic species mainly Chamephytes; anthropogenic ecotopes (Type III) such as "Garden" and "Town boundary" with Archaeophytes and exotic Neophytes mainly Phanerophytes; while "Humid margins" and mixed ecotopes (Type II) are linked to feral species and mainly to hemi-cryptophytes and therophytes. Minimum spanning tree of the habitat features traced by the floristic biological heritage is consistent with the pedogenetic relationships between primary mother rocks, their derived ecotopes and anthropogenic impacts. Ecotope ranking based on its biodiversity value indicates that appropriate simultaneous conservation of both genetic resources and human works is achievable.
\end{abstract}

\section{Keywords}

Biodiversity, Ecotope, Habitat, Heritage, In Situ Conservation 


\section{Introduction}

Biogenetic linkages among ecotopes within habitat rise theoretical considerations about the interaction between environment and phenotype. A current thesis, clearly wrong, considers the environment of an organism independent of that organism, and the changes that occur in the environment to be autonomous and independent of the changes that occur in that organism. This thesis leads to the hypothesis that environments exist without species. The correct reading of the definition of habitat and, a fortiori, of ecosystem indicates that an empty ecological niche is not conceivable [1]. The vital activities of organisms and their relevant aspects that can be identified through their presence allow us to identify the environment that is relevant to them. In general, the spatial distribution of species can be understood whether the environment is seen as a space defined by the vital activities of organisms rather than as a physical component. Not only do organisms determine which part of the outside world is most appropriate to their living conditions but, through their vital activities, they build the environment around them. At the extreme end of this process is the global anthrome widening due to human population growth [2]. Based on the degree of species specialization it is possible to link biogenetically the whole set of ecotopes within heterogeneus habitats.

Plant community, in the composition of an anthropogenic landscape, can be perceived as a pleasant attribute or as a disturbance. This dichotomy derives from the human perception that oscillates between the Humboldtian [3], Darwinian [4] view, according to which green coverage is the landscape main ornament, thus contributing to its composition, structure and function [5] and the anthropocentric conception, according to which flora, whether native or introduced [6], is a disturbance factor [7] [8] or, even, danger to man [9]. The management of Unesco cultural sites is trained by this dual vision. Basically, the management of cultural Sites considers the conservation of human works as a priority; for natural Sites priority is given to the conservation of biodiversity and the mixed ones should allow the overlapping of the two strategies. Of the world Unesco sites, 869 are cultural, 213 natural and 39 mixed $^{1}$. Some cultural sites, including many archaeological sites, fit into much more diverse landscapes already recognized by the Unesco World Heritage Committee as "Cultural Landscapes" as they combine "works of nature and of man" ${ }^{2}[10]$. However, the same criteria adopted to outline the Cultural Landscapes are also valid for those cultural Sites where in the "Brief Synthesis" in supporting the "Outstanding Universal Value" the high landscape value is highlighted in relation to a larger territorial scale that can also contain a "buffer zone" [11]. In addition, the definition of "Historic Urban Landscape" considers the integration into the Site of a "broader urban context and its geographical setting" [10]. The Italian Site "The Sassi and the Park of the Rupestrian Churches of Matera" [12] which includes the "Ancient

${ }^{1}$ https://whc.unesco.org/en/list.

${ }^{2} \mathrm{https} / / /$ whc.unesco.org/en/culturallandscape/. 
City of Sassi", so-called "Matera-Sassi" (MS), is an example of a cultural site in the territorial area of landscape importance.

It is known that flora of anthropized landscapes includes both native and man-introduced species (ornamental and food archaeophyte taxa) since the distant past [13]. The functional importance of floristic genetic diversity in anthropogenic habitats has been under-estimated in the past: in agricultural habitats, in fact, in Italy, about 250 among mono and dicot species have been generally interpreted as unwanted entities (weeds) [7] although the sustainable production of food, on the contrary, even in agri-ecosystems, could benefit from the increase of diversity of some of these species [14]. From the purely subjective perception, the green coverage of landscape units is positively correlated with quality of life [15]. Across the Mediterranean Region in the historic centers, both inhabited and abandoned, in archaeological areas, biodiversity studies indicate a high floristic richness, sometimes higher than that found in other habitat types conditioned by anthropogenic activities. De Natale \& La Valva [16] in the floristic survey of the Unesco cultural site "Ancient historic center of Naples", over an urban area of about $40 \mathrm{~km}^{2}$ they found a high species richness (659 species) correlated to human activities. Also, a biodiversity hotspot has been identified in the city of Ioannina [17]. Biodiversity studies indicate in a direct way that cultural heritage is connected with biodiversity heritage. A complementary approach based on the integration of biodiversity conservation into human works conservation would represent an opportunity to improve the effectiveness and efficiency of management plans. In this study, the vascular flora of the ancient city MS has been used as a biogenetic indicator for ecotope evaluation/ordination with the perspective to put into practice the in-situ conservation of bio-genetic resources and habitat integrity conservation.

\section{Matera-Sassi Habitat}

MS is a historic settlement [18], located on the w-slope of the Matera Kenyon, whose shape is like a couple of "funnels" that remember "Dante's hell" [19] (Figure 1). During Fascism, it was inhabited by 13,000 peoples living far below the usual standard; following its evacuation during the fifty of the last century, it was completely abandoned [20]. The site, partially rehabilitated, due to its charm, often has performed as set for movie-makers and, in the last decade, its regeneration induced a significant touristic pressure. The settlement is composed of districts (Civita, Barisano, Caveoso and Casalnuovo) that cover an urbanized mosaic of ecotopes ranging from quasi-natural to man-made types over an area of about $38 \mathrm{ha}$. This area at high altitude is merged with the modern city of Matera, at the lowermost ends on the natural habitat of the city Kenyon (Figure 1). The geological substrate consists of Pleistocene limestone rocks (calcarenite of Altamura) and the historic houses are built with blocks of limestone in direct continuity with the limestone of caves and hypogea. There are impluvia, hypogea, bleachers and connecting alleys paved with limestone separated by natural soil (Figure 5). The Site geomorphology is shaped by the Kenyon slope 


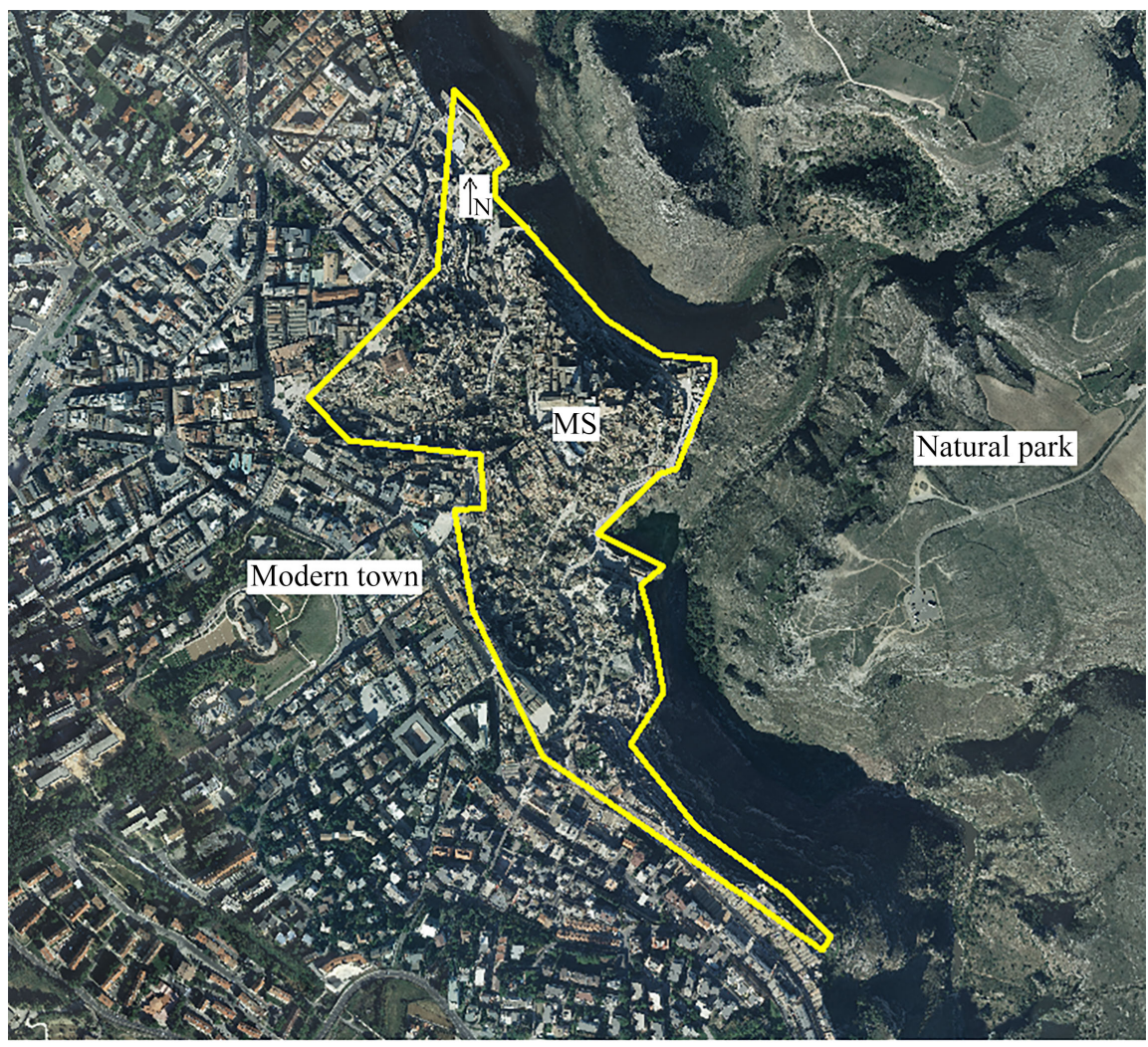

Figure 1. The ancient city of Matera-Sassi (MS) is located in the western slope of the Kenyon between the modern town and the natural park area.

which is compensated by the arrangement of the buildings according to the level curves and soil terracing [21] (Figure 1).

The steep slope and the prevailing orientation towards the East-North-East, exposes the settlement to the Adriatic quadrant and it doesn't allow an oblique incidence of the sun's rays in the morning and afternoon. Nonetheless, the Site is protected from cold Balkan winds through the opposite Kenyon slope. Because of this geomorphology the local microclimate could significantly affect the vegetation of the place. Together with the weather conditions, both the porous structure of the limestone substrate and its thermal inertia, define an ecological niche suitable for taxa that would have been impacted by warm and dry quarters elsewhere. Overall, the chemical continuity between the building calciophile materials and the pedogenetic substrate determines a sub-alkaline environment for root plants. Nonetheless, in some cases, acidophilic niches are present as the result of organic material accumulating in the presence of high relative humidity.

\section{Method}

\subsection{Bioclimatic Characterization}

Data from the world climate database ${ }^{3}$ with a spatial resolution of 30 arc-second ${ }^{3}$ https://www.worldclim.org/. 
have been used. The macroclimate was determined with the Rivas Martinez index [22] using the following formula.

$I_{o}=\left(P_{\text {june }}+P_{\text {july }}+P_{\text {August }}\right) /\left(T_{\text {june }}+T_{\text {july }}+T_{\text {August }}\right)$ where $P$ represents precipitation in $\mathrm{mm}$ and $T$ the average temperature of three months. The macroclimate is Mediterranean if $I_{o}<1.5$; temperate if $I_{o}>2$ and transition if $1.5<I_{o}<2$. The bioclimate of the site has been estimated either with the Emberger index [23] or De Martonne index [24].

The following formula has been adopted for Emberger index: $Q=P \times$ $2000 /\left(M^{2}-m^{2}\right)$; where $P$ is the annual precipitation in $m m, M$ the average of the maximum temperature of the hottest month (in ${ }^{\circ} K$ ), $m$ the average of the minimum temperature of the coldest month (in ${ }^{\circ} K$ ). The denominator $\left(M^{2}-m^{2}\right)$ is the range representing the continentality index.

The following formula has been adopted for De Martonne index: $I=P /(t+$ 10 ); where in addition to $P$ (annual precipitation) it is considered $t$ (average annual temperature in ${ }^{\circ} \mathrm{C}$ ).

Both Emberger and De Martonne indices classify the climate in the following categories: Hyper humid $(I>60, Q=150)$, Humid $(I=30-60, Q=98-150)$ Sub-humid ( $I=20$ - 30, $Q=57$ - 98), Semi-arid $(I=15-20, Q=30-57)$ Arid ( $I$ $=5-15, Q=17-30)$, Hyper arid $(I=0-15, Q=0-17)$.

The estimates of above indices and the annual trends (e.g., average annual temperature, annual precipitation) seasonality characteristics (e.g., annual temperature and precipitation ranges) and extreme or limiting factors on biological processes (e.g., colder and warmer month temperatures, wet quarter and dry quarter precipitation) are reported in Figure 2.

\subsection{Biodiversity Analysis}

The ancient town of MS including its borders (Figure 1) was sampled (May 2015) according to the degree of accessibility in areas, each one composed of ecologically distinct landscape features (ecotopes) [25].

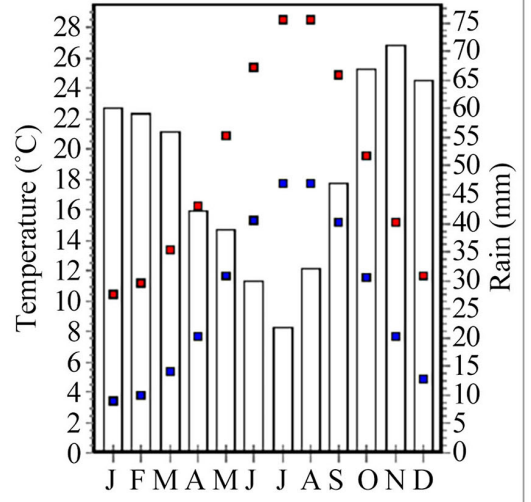

Figure 2. Bioclimatic variables of Matera-Sassi. Average monthly min and max temperatures; average monthly precipitations (left) and bioclimatic variables (right).

\begin{tabular}{ll}
\hline Bioclimatic Variable & Value \\
\hline Rives Martinez index [I $]$ & 1.26 \\
De Martonne index [I] & 24.1 \\
Emberger index [Q] & 81.2 \\
\hline Annual Mean Temperature [1] & 14.5 \\
Mean Monthly Temperature Range [2] & 8.7 \\
Isothermality (2/7) $(* 100)[3]$ & 34.5 \\
Temperature Seasonality (STD * 100) [4] & 606.8 \\
Max Temperature of Wamnest Month [5] & 28.5 \\
Min Temperature of Coldest Month [6] & 3.4 \\
Temperature Annual Range (5-6) [7] & 25.1 \\
Mean Temperature of Driest Quarter [9] & 22.2 \\
Mean T emperature of Warmest Quarter [10] & 22.2 \\
Mean T emperature of Wettest Quarter [8] & 11.8 \\
Mean T emperature of Coldest Quarter [11] & 7.5 \\
Annual Precipitation [12] & 590 \\
\hline
\end{tabular}


The overall habitat is a mosaic of different ecotopes a-priori identified as: "Boundary" of the lower side of the city, "Limestone" summit ridges emerging between the man-made structures, "Walls" of the houses, "Roofs", "Margins" of road pavements, "Humid margins" of alleys streets and inhabited ruins, rural "Gardens", mixed ecotopes such as "Limestone-Wall" and "Limestone-Margin".

The Pleistocene limestone is the autogenic factor determining the nature of the edaphic substrate of "Limestone" summit ridges, "Walls" of houses and "Roof" materials (ecotope type I). While the soil accumulation in the "Margins", "Garden" soils and the city "Boundary" edaphic environment could be in part allogenic (ecotope type III). Mixed ecotopes such as "Limestone-Wall" and "Limestone-Margin" have been assessed as a different ecotope category (ecotope type II) [25].

Floristic entities have been assessed taxonomically as proposed by Pignatti [26] according to the biological and chorological category. In particular, the following main biological forms have been identified based on Raunkiaer's system: " $\mathrm{T}$ " = therophytes; "G" = geophytes; " $\mathrm{H}$ " = hemicryptophytes; "Ch" = chamephytes; "NP" = nanophanerophytes; "P" = phanerophytes. Chorological forms have been traced back to the following main geographical categories: Mediterranean, European, Cosmo- or Sub-cosmopolitan, Paleotropical, Circumboreal, Asian, Endemic, Sub-endemic, North or South-American, South-African [26]. Native species have been distinguished from those introduced from other areas of diffusion. Archaeophytes and neophytes were both identified and slight variations in taxon attributes that do not alter the classification according to Pignatti [26] were based on the updated Italian flora checklist ${ }^{4}$. Floristic entities introduced in recent years for tourist and ornamental purposes, of doubtful ecologic suitability, have not been included in our database.

Taxon frequency and abundance have been recorded and taxon spatial distribution was delineated according to the following categories: entities distributed "locally" (present in the sampling zone) and "widely" (present in several sampling areas), performing within each ecotope as "rare" in terms of abundance ( $<10 \%$ coverage) or "common" ( $>10 \%$ coverage).

Relationships between ecotope and distribution pattern of plant community were assessed by multivariate analysis [27] in order to validate the most relevant ecotopes for in situ conservation of plant biodiversity.

Both the analysis of correspondences and the analysis of the principal components served to describe the structure of MS plant diversity [28]. Correspondence analysis [29] has been adopted as an ordination method to find relationships between ecotope and flora types respectively [30]. Ecotope has been used as ecological variable and the frequency of the 6 Raunkiaer's biological types, the 11 chorological categories, the type of spatial distribution (localized or widely distributed) and the frequency of invasive species as predictor variables. The main advantages of correspondence analysis are: 1) Simultaneous ordination of ${ }^{4}$ http://dryades.units.it/floritaly/. 
the ecological variables and the biogenetic units. 2) Standard deviation units are reported on the axes.

Principal components analysis [28] has been adopted to find components accounting for as much as possible of the variance in multivariate data in order to identify meaningful relationships among ecological units; the ecotope units, in this study, have been visualized in the multivariate space through the minimum spanning tree. The combination of correspondence and principal component analysis allowed the description of the biodiversity structure at habitat-level allowing the relative ranking of each ecotope for taxon in situ conservation [31].

\section{Results}

\subsection{Climate}

The annual precipitation is $590 \mathrm{~mm}$, with an average annual temperature of $14.5^{\circ} \mathrm{C}$ (Figure 2). The coldest month (January) has an average temperature between $3.4^{\circ} \mathrm{C}$ and $10.4^{\circ} \mathrm{C}$; the hottest month is July and August (average $T_{\max }=$ $\left.28.5^{\circ} \mathrm{C}\right)$. The first quarter is the coldest $\left(T_{\text {mean }}=7.5^{\circ} \mathrm{C}\right)$ and the last the wettest $\left(\mathrm{H}_{2} \mathrm{O}=203 \mathrm{~mm}\right)$. The third quarter at the same time is both the driest $\left(\mathrm{H}_{2} \mathrm{O}=84\right.$ $\mathrm{mm})$ and the hottest $\left(T_{\text {mean }}=22.2^{\circ} \mathrm{C}\right)$. The area of the Site is characterized by Mediterranean macroclimate $\left(I_{o}=1.26\right)$ and sub-humid facies $(Q=81.2 ; I=$ 24.1) (Figure 2). MS climatic parameters are consistent with the phytoclimatic belt "Lauretum of the second type (with summer drought) medium sub-zone", which is the transitional zone from warm sub-zone to the cold one [32]. The average annual thermal excursion $\left(25.1^{\circ} \mathrm{C}\right)$ is about $2^{\circ} \mathrm{C}$ higher than that of Naples (Lauretum warm sub-zone), in fact the temperatures are on average $2.2^{\circ} \mathrm{C}$ lower in the wettest quarter, with significantly lower precipitation of about $100 \mathrm{~mm} /$ year. Nonetheless, MS microclimate because of the described site-specific geomorphology (Figure 1) can be cooler during the warm quarter and warmer during the cooler quarter. The smoothing of thermal excursion together with dampness of deep and shallow corners, determine the ecological conditions for several species rare or absent outside (e.g., Campanula versicolor L., Centranthus ruber (L.) Dc., Capparis spinosa L., Cymbalaria muralis Hill, Crepis spp., Lavathera arborea L.) and common in this refuge habitat/area.

\subsection{Flora of Matera-Sassi}

The total richness amounts to 190 species belonging to 59 different botanical families, reordered according to the geographical range of distribution in 11 broad chorological groups and in 6 types of biological forms (Figure 3). The $80 \%$ are native species, $16 \%$ are introduced species half of which are archaeophytes, $4 \%$ cryptophytes. Overall, $4 \%$ (5 neophytes plus 2 archaeophytes) are considered invasive species.

The most represented (47\%) are Mediterranean species. Species with a prevailing European distribution as well as those with wide global distribution (cosmopolitan, sub-cosmopolitans) are both moderately represented (17\%). 

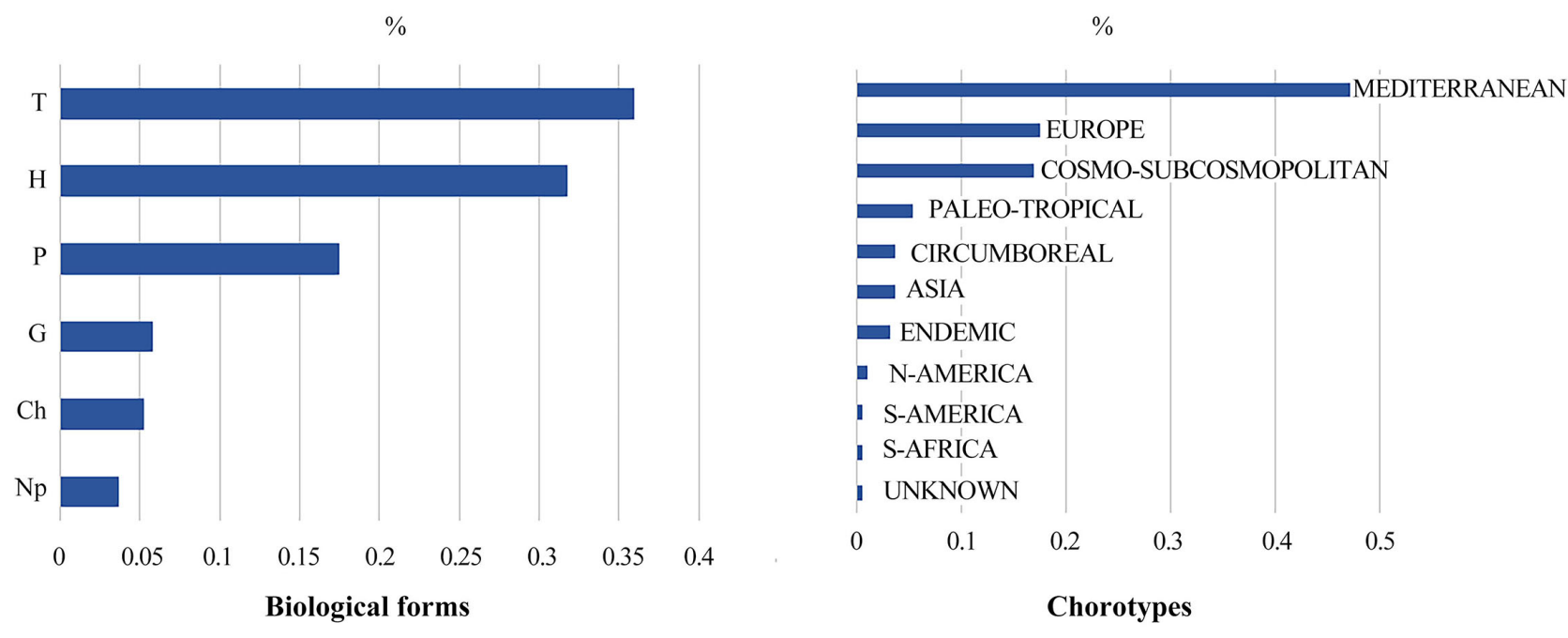

Figure 3. Frequency of the Raunkier's biological forms (left) and of the main chorotypes (right) of Matera-Sassi flora.

Some, with low frequency $(<5 \%)$, are Endemic, Sub-endemic, Asian or Circum-boreal respectively (Figure 3). This distribution is consistent with that reported by De Natale \& La Valva [16] for the historic center of Naples, where unlike MS the frequency of widely distributed species across the globe increases (34\%). Among the Mediterranean species those with Euro-Mediterranean areal (n. = 33) are more prevalent than the Steno-Mediterranean (n. = 21).

Endemic species are: Dianthus garganicus (Ten.) Brullo, Leontodon apulus (Fiori) Brullo, Centaurea deusta Ten., Crepis lacera Ten., Campanula versicolor and Scabiosa pseudisetensis L. Sub-endemic species are: Crepis corimbosa Ten., Helianthemum jonium Lacaita.

Species performing as invasive $e^{5}$ very well adapted to the local microclimate are: Ailanthus altissimus Desf., Conyza canadensis Less., Opuntia ficus indica (L.) Miller., Aster squamatus (Spreng.) Mr Hieron., Agave americana L., Arundo donax L. In this study we found in abandoned gardens also remnant isolated feral individuals of medicinal plants (e.g.: Papaver somniferum L., Hyoscyamus niger L., Matricaria chamomilla L., Malva sylvestris L. and Ferula communis) as well as potherbs such as Diplotaxis spp., Sinapis spp., Sonchus spp. and Crepis spp. Margins and border embankment (type III) are more significantly affected by the anthropogenic impacts. Here invasive species became dominant. Nonetheless, not all the weeds are invasive: Several species performing as selfperpetuating ruderal open-pollinated populations (e.g., Sinapis alba L.; Ferula communis) are of great scientific value because of their genetic properties in order to improve the cultivated varieties as well as for their widely recognized anthropological value.

Few others entities are exotic neophytes represented by one or a few individuals with ornamental function (Yucca gloriosa L., Polygala myrtifolia L., Aloysia citrodora Palau, Ligustrum lucidum Aith.).

The biological Raunkiaer's form reflect the biological adaptation of each spe${ }^{5}$ http://dryades.units.it/floritaly. 
cies especially in relation to overcoming the most unfavorable season, which, for this site, is certainly June-August rather than the cold quarter (Figure 2). Therophyte is the most prevailing form (36\%), half of which with Mediterranean range and the remainder by widely spread species (sub-cosmopolitan and cosmopolitan). High (32\%) is also the incidence of Hemi-cryptophytes. These include species with a Mediterranean-European spread, followed by species with wide distribution over the globe. Phanerophytes (17\%) have been found, on average, in the terraces, embankments and gardens. Geophytes and Chamephytes are both present with low frequency (5\%). Nano-phanerophytes are the rarest forms (3\%). The percentage of the presences of each biological class is consistent with what has already been reported for the historic center of the city of Naples [16].

\subsection{Biodiversity Patterns}

The relationships among ecotopes and biological variables revealed by discriminant multivariate analyses are shown in Figure 4 and Figure 5. In Figure 4 axis 1 deploys much of the variability in the multivariate space $(\lambda=0.23)$ with a higher score contribution due to "Garden" and "Town-boundary", while as far as biological variables are concerned, a high score contribution is due to the exotic chorotypes and Phanerophytes. For axis $2(\lambda=0.09)$ the largest contribution is due to "Pleistocene limestone" and "House wall", while for biological variables a high score contribution is due to Endemic species and Chamephytes. All the above variables are external to the space represented by the ellipse that captures $95 \%$ of data (Figure 4 ).

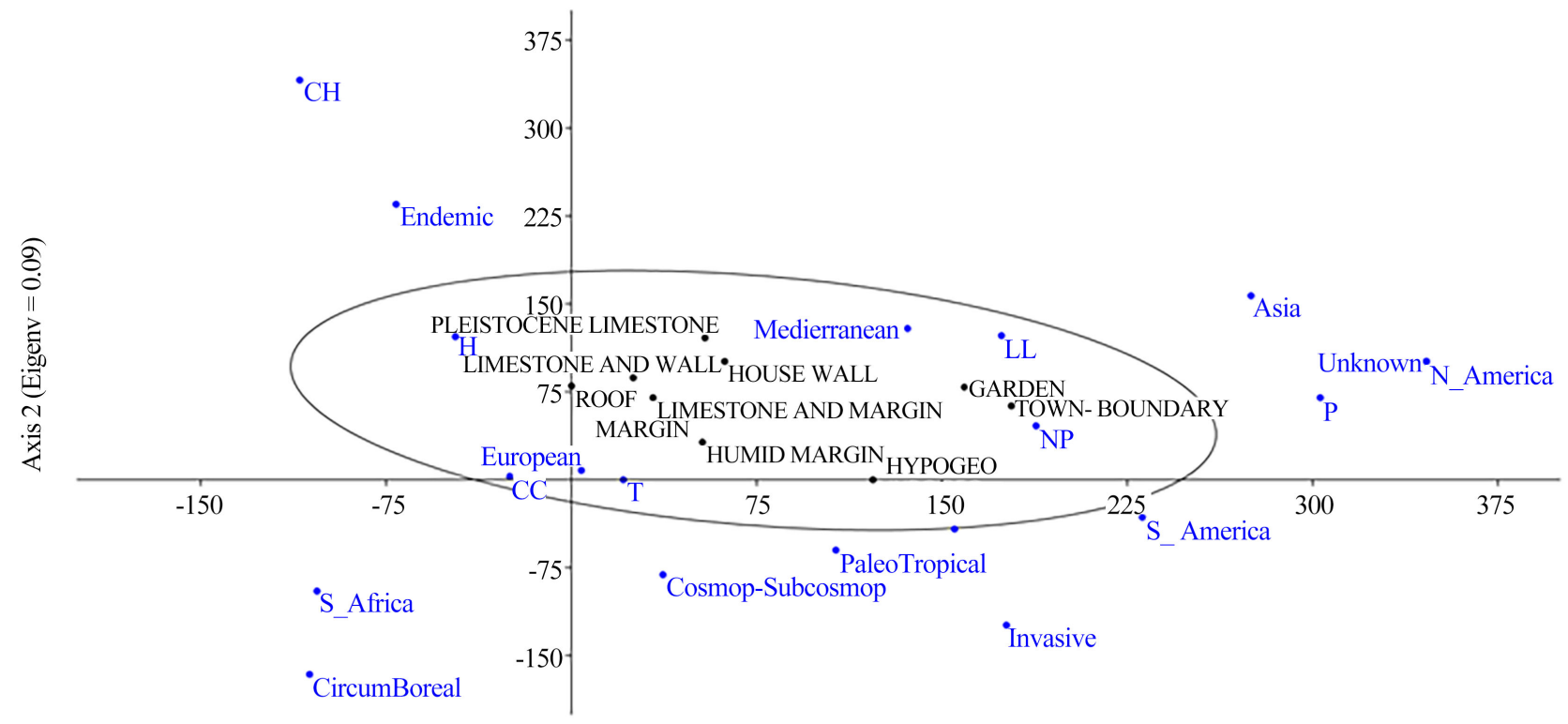

Axis $1($ Eigenv $=0.23)$

Figure 4. Detrended correspondance analysis plot among biological variables and ecological basic units (ecotopes). Species spatial distribution labels: $\mathrm{CC}=$ common and widely distributed species and LL = very localized species; biological form labels: $\mathrm{CH}=$ chamephytes, $\mathrm{H}=$ hemicryptophytes, $\mathrm{T}=$ therophytes, $\mathrm{NP}=$ nanophanerophytes, $\mathrm{P}=$ phanerophytes and $\mathrm{G}=$ geophytes. 


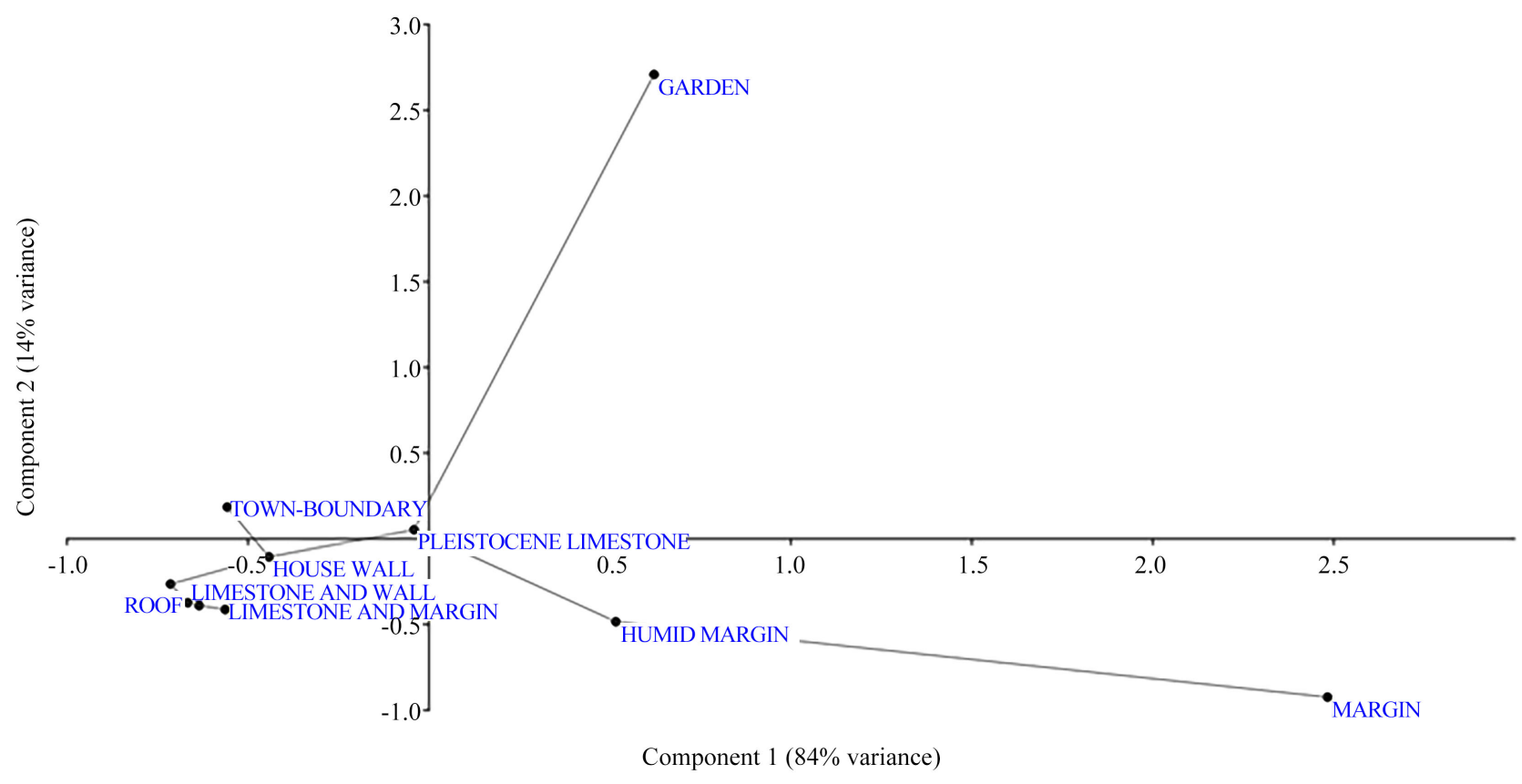

Figure 5. Component principal analysis plot shows the spanning tree depicting the biogenetic linkage among the ecological basic units (ecotopes).

Therefore, on a multivariate basis, the following three types of relationships can be viewed:

1) Ecotopes represented by both humid and dry "Margins" predominantly capture Therophytes and Hemi-cryptophytes with predominantly EuropeanMediterranean chorology and are represented by common and widely distributed species (CC) over MS habitat. Asteraceae and grasses among the Hemicryptophytes are associated also with "Margins".

2) "Pleistocene limestone", tuff walls and roofs are prevalently associated with different family groups of Chamephytes and Hemi-cryptophytes. The whole set of endemic species recorded are associated with this type of ecologic substrate.

3) "Gardens" and "Town boundary" mostly localize Mediterranean and Paleo-temperate Phanerophytes as well as Nano-phanerophytes. Taxa belonging to these biological forms show a very localized distribution (LL). This group of species includes, above all, neglected ancient fruit tree individuals located in rural gardens: Punica granatum L., Olea europaea L., Ficus carica L. var domestica L., Vitis vinifera Subsp. vinifera L., Juglans regia L., Morus alba L., Prunus domestica L., P. dulcis L., Laurus nobilis L., Eryobotria japonica Lindley and Citrus limon (L.) Burm. $f$. Such domesticated germplasm is the most evident legacy of the peasant ancient civilization [19]. "Town boundary", physically represented by the lower edge of the ancient city, is colonized by Paleo-tropical and South American invasive species: Ailanthus altissimus, Opuntia ficus indica, Agave americana.

Additionally, the ecological relationships among different ecotopes are also revealed by the minimum distances in the space defined by the axes of the first two main components ( $\mathrm{PC} 1$ and $\mathrm{PC} 2$ ) which explain $84 \%$ and $14 \%$ of variance respectively (Figure 4). PC1 distances among ecotopes are due mainly (load- 
ings $> \pm 0.10$ ) to the following variables: type of spatial distribution (localized or widely distributed); biological form (Therophyte and Hemi-cryptophyte); chorotype (Mediterranean, Cosmo-Sub cosmopolite and European). These categories of biodiversity, all with positive values of loading factors, contribute to separate the type I ecotope represented by the mother rock ("Pleistocene limestone") from type III ecotope (“Garden", dry and humid "Margin") With regard to PC2, the Phanerophyte form help to separate the position of the Gardens upwards (Figure 4). In short, from "Pleistocene limestone" are departing three branches that lead respectively in the direction of "Garden" (first branch), "Margins" (second branch), and "House" structures such as walls, roofs and hypogea (third branch). Such a minimum spanning tree is consistent with the pedogenetic relationship between primary mother rocks and their most close derived ecotopes such as tuff building materials represented by the typical bricks composing walls, roofs and hypogea. While niches due to the accumulation of substrates in the corners of roads and ruined areas as well as the gardens represent more diverse anthropogenic units. Ecological units close to each other experienced more correlated genetic and environmental conditions than those far away each other. According to these results, native and Endemic taxa are associated to type I ecotopes while Neophytes prefer the colonization of "Margins" and "Boundary".

\section{Discussion}

MS displays a significantly higher species density than Naples historical center [16] and it performs as a refuge niche for a valuable component of plant species diversity. In addition, the Site is a connection path between the park landscape and the modern town (Figure 1). Overall, with reference to Unesco sites bearing landscape relevance, it is necessary to take into account, for management planning, the whole landscape context, assuming that changes of the physical environment are linked to changes in species composition and abundance. Accordingly, based on landscape relevance Brasioli [33] classifies the Italian Unesco Sites in: 1) Cultural Landscapes; 2) Historical urban landscapes; 3) Natural sites; 4) Cultural sites in territorial areas of landscape importance. "The Sassi and the Park of the Rupestrian Churches of Matera" is, therefore, classified as a cultural site in the territorial area of landscape importance. It is considered "an example of continuity of anthropogenic settlement within the Mediterranean landscape and harmony between ecosystem and human activities since the Neolithic phase" [12]. The "Ancient City of Sassi" (MS) declared to be "one of the most evocative landscapes of the Mediterranean" [12] is bordered by a buffer strip of quasi-natural habitats included in the Regional Park and by the town of Matera (west side). Based on Brasioli's classification [33] this Site should be managed as "Cultural site in the territorial context of landscape importance"; then the conservation of MS historical-architectural heritage should overlap with the conservation of the biodiversity contained in it. Landscape analysis taking into account both genetic [31] and physical features [34] may be helpful for management planning. 


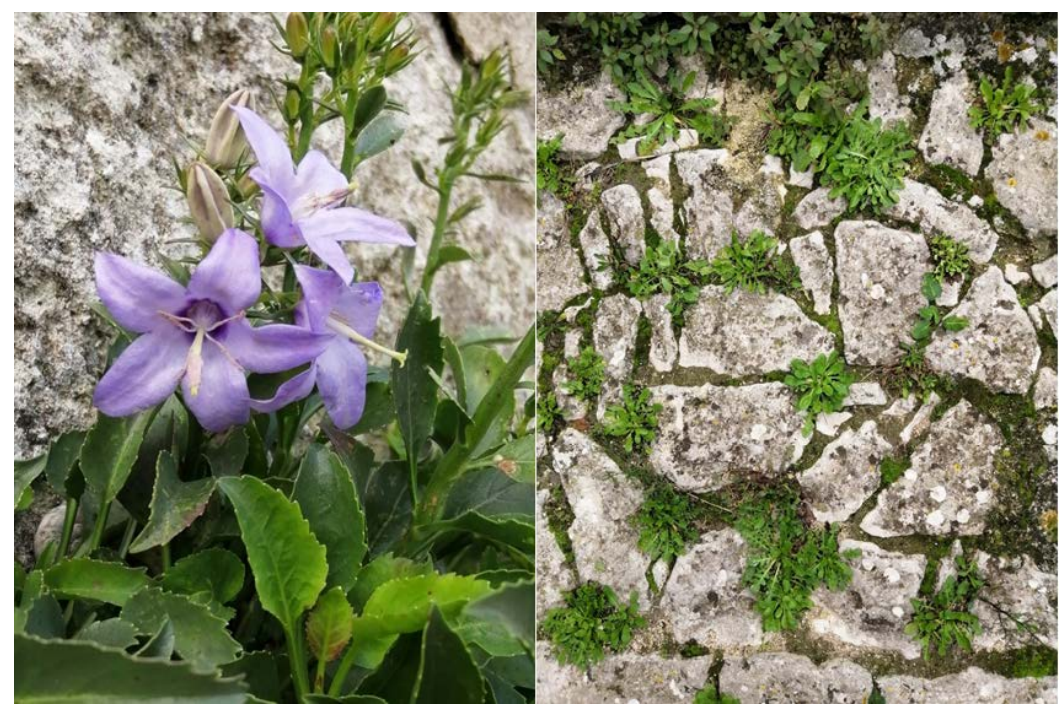

Figure 6. Campanula versicolor L. on traditional house walls (left) and hemi-criptophyte species richness in between the alley stone margins (right).

\section{Conclusion}

MS is a mosaic of ecological units, shaped by different degrees of anthropogenesis, converging in three different ecotope categories, each one bearing significant components of biodiversity in their plant community (Figure 6). Ecotope type I and type III are relevant for their endemic rare wild species and ancient fruit trees respectively. In particular, ecotopes type I are refugia for specimens with high visual value, rare elsewhere in the wild. The abundance of these taxa would promote visitor interest because of their attractiveness. Ecotope III and margins in mixed ecotopes (type II) are marked by potherbs, feral medicinal and invasive species. In order to manage appropriately the Site, special emphasis should be given either to rare/endangered or to functional species. Of human interest are the endemic and sub-endemic species, domesticated archeophytes, their wild relatives, species of scientific, aesthetic and social interest. In situ genetic conservation is a priority for these species. In contrast entities with possible concern to humans and habitat, such as invasive and allergenic species must be properly managed.

\section{Acknowledgements}

This paper has been realized within the project "BIOGOVUNESCO"-FersBasilicata 2014-2020.

\section{Conflicts of Interest}

The authors declare no conflicts of interest regarding the publication of this paper.

\section{References}

[1] Lewontin, R.C. (2002) Gene, organismo e ambiente. Laterza, Bari, 1-108. 
[2] Martin, L.J., Quinn, J., Ellis, E.C., Shaw, M.R., Dorning, M.A., Hallett, L.M., et al. (2014) Conservation Opportunities across the World's Anthromes. Biodiversity Review, 20, 745-755. https://doi.org/10.1111/ddi.12220

[3] Von Humboldt, A. (1808) Ansichten der Natur. Quadri della Natura, Codice Edizioni, Torino 2018.

[4] Darwin, C. (1845) The Voyage of the Beagle. The Collier Press, New York, 1-545. https://Archive.org

[5] Darwin, C. (1859) On the Origin of Species by Means of Natural Selection. 1st Edition. Italian Translation by G. Pancaldi (L'origine delle Specie). BUR, Rizzoli, 2009, 1-566.

[6] Bardsley, D. and Edwards-Jones, G. (2006) Stakeholders' Perceptions of the Impacts of Invasive Exotic Plant Species in the Mediterranean Region. GeoJourna, 65, 199-210. https://doi.org/10.1007/s10708-005-2755-6

[7] Viggiani, P. and Angelini, R. (2002) Dicotiledoni spontanee e infestanti. Bayer, Milan, 1-533.

[8] Viggiani, P. and Angelini, R (2002) Erbe spontanee e infestanti: Tecniche di riconoscimento, graminacee. Bayer, Milan, 1-352.

[9] D’Amato, G., Cecchi, L., Bonin, S., Nunes, C., Annesi-Maesano, I., Behrendt, H., Liccardi, G., Popov, T. and van Cauwenberge, P. (2007) Allergenic Pollen and Pollen Allergy in Europe. Allergy, 62, 976-990. https://doi.org/10.1111/j.1398-9995.2007.01393.x

[10] World Heritage Center (WHC1) (2019) The UNESCO Recommendation on the Historic Urban Landscape. World Heritage Center, Paris, 1-27.

https://whc.unesco.org/en/hul

[11] World Heritage Center (WHC2) (2019) Operational Guidelines for the Implementation of the World Heritage Convention. World Heritage Center, Paris, 1-197. https://whc.unesco.org/en/guidelines/

[12] ICOMOS (International Council on Monuments and Sites) (1993) Advisory Body Evaluation. Unesco Decision N. 670. http://whc.unesco.org/en/list/670/documents/

[13] Sereni, E. (1961) Storia del paesaggio agrario. Laterza, Bari, 1-500.

[14] Pikett, C.H. and Bugg, R.L. (1998) Enhancing Biological Control: Habitat Management to Promote Natural Enemies. University of California Press, Berkeley, 1-405.

[15] Yuan, L., Shin, K. and Managi, S. (2018) Subjective Well-Being and Environmental Quality: The Impact of Air Pollution and Green Coverage in China. Ecological economics, 153, 124-138. https://doi.org/10.1016/j.ecolecon.2018.04.033

[16] De Natale, A. and La Valva, V. (2000) La flora di Napoli: I quartieri della città. Webbia, 54, 271-373. https://doi.org/10.1080/00837792.2000.10670681

[17] Kantsa, A., Tscheulin, T., Junker, R.R., Petanidou, T. and Kokkini, S. (2013) Urban Biodiversity Hotspots Wait to Get Discovered: The Example of the City of Ioannina, NW Greece. Landscape and Urban Planning, 120, 129-137. https://doi.org/10.1016/j.landurbplan.2013.08.013

[18] Giura Longo, R. (1970) Sassi e secoli. Galleria Studio, Cifarelli, Matera, 1-120.

[19] Levi, C. (1945) Christ Stopped at Eboli. Einaudi, Torino, 1-250.

[20] Valente, M. (2007) Evoluzione socio-economica dei Sassi di Matera nel XX secolo. Consiglio Regionale della Basilicata, 1-146.

[21] Laureano, P. (2012) Giardini di pietra. I Sassi di Matera e la civiltà mediterranea. Bollati Boringhieri, Torino, 1-207. 
[22] Rivas-Martinez, S. (1996) Bioclimatic Map of Europe. In: Rivas-Martinez, S., Ed., Geobotanica y climatologia, Universidad de Granada, Granada, 25-98.

[23] Emberger, L. (1930) La végétation de la région méditerranéenne: Essai d'une classification des groupements végétaux Revue Générale de Botanique, 42, 641-662+705721.

[24] De Martonne, E. (1926) Une nouvelle function climatologique: L'indice d'aridité [A New Climatological Function: The Aridity Index]. La Meteorologie, 2, 449-458.

[25] Tansley, A.G. (1946) Introduction to Plant Ecology. London George Allen \& Unwin Ltd., London. https://www.archive.org

[26] Pignatti, S. (2003) Flora d'Italia, 1-3. Edagricole, Bologna.

[27] Hammer, Ø. and Harper, D.A.T. (2006) Paleontological Data Analysis. Blackwell, Oxford. https://doi.org/10.1002/9780470750711

[28] Legendre, P. and Legendre, L. (1998) Numerical Ecology, 2nd English Edition, Elsevier, Amsterdam, 1-853.

[29] Hill, M.O. and Gauch, H.G. (1980) Detrended Correspondence Analysis: An Improved Ordination Technique. Vegetation, 42, 47-58. https://doi.org/10.1007/BF00048870

[30] Oxanen, J. and Minchin, P.R. (1997) Instability of Ordination Results under Changes in Input Data Order: Explanations and Remedies. Journal of Vegetation Science, 8, 447-454. https://doi.org/10.2307/3237336

[31] Frankel, O.H., Brown, A.H.D. and Burdon, J.J. (1995) The Conservation in Situ of Useful or Endangered wild Species. In: Frankel, B. and Burdon, Eds., The Conservation of Plant Biodiversity, Cambridge University Press, Cambridge, 148-175.

[32] Cantore, V., Iovino, F. and Pontecorvo, G. (1987) Climatic Traits and Phytoclimatic Belts of Basilicata. National Research Council, Istituto di Ecologia e Idrologia Forestale, 2, 1-34.

[33] Brasioli, T. (2017) I Piani di Gestione italiani dei siti Unesco: Quadro sinottico. In: MiBACT, Rapporto sullo stato delle politiche per il paesaggio, Ministero dei Beni e delle Attività Culturali e del Turismo \& Osservatorio Nazionale per la qualità del paesaggio, Rome, 329-333.

[34] Tansley, A.G. (1939) The British Isles and Their Vegetation. Cambridge University Press, Cambridge, 1-494. 